\title{
Language and Authority in Celestina: Institutions, Incongruence and Shifting Symbolic Power
}

\author{
Emma Gatland \\ Trinity Hall - University of Cambridge
}

George Shipley writes that in Celestina verbal facility is a characteristic shared by almost all of Fernando de Rojas's creatures (1968: 107). Shipley, however, goes on to note that "the power inherent in the word operates "transitively" in the world spoken of; projected from speaker-subject, the word predicates what it names» (1968: 107). Bound up in Shipley's two statements are three necessary syllogisms. The first is that there exist multiple worlds, other than and different to the world "spoken of» (Shipley 1968: 107). The second is that language operates both within and according to Rojas's fictional world(s) and, at the same time, entails its/ their very existence. The third is the notion that language has contradictory values and, consequently, that linguistic power can be continually transmuted. It is the changes in linguistic authority together with their implications for individual power that I shall explore here with specific reference to the two principle female characters of the narrative, Melibea and Celestina. I shall consider how verbal mastery is gained and lost, and why it shifts; how changes in verbal facility relate to the different fictional worlds — created in and by language - in which the characters reside and between which they move; and whether language in Celestina is a forever-shifting force that destabilizes as much as it empowers.

In order to approach these questions effectively, I shall make use of theory propounded by French sociologist Pierre Bourdieu (1990, 1991) on language and symbolic power, which tacitly acknowledges the legitimacy of linguistic authority according to the social constructions in which it is embedded. In the same way that Shipley considers the word in Celestina to predicate what it names, Bourdieu's basis for linguistic 
power is both structured by and structures in its turn the social conditions within which it is acquired. I believe that one of the key strengths of Bourdieu's theory is its ability to explore positions of speaker-subjects - and interrelations between speaker-subjects- as determined by the distribution of different kinds of resources or capital, and the conversion of one form of capital (for example, economic) into another (such as symbolic). Applied to Celestina, a work in which economic and commercial underpinnings, social relations, and linguistic authority continually merge, Bourdieu uniquely provides us with a framework with which to examine the struggles and degree of success of individuals in Rojas's work to seek, maintain, or alter the distribution of power, in terms of capital gain and capital loss. Onto Rojas's fictional worlds, then, I shall map Bourdieu's practical «institutions", which are "any relatively durable set of social relations that endows individuals with power, status and resources» (1991: 8). On this basis, the courtly world in which Melibea resides at the beginning of the work, and the contrasting, base world of prostitution, black magic, and bawdry of Celestina both satisfy the criteria of being relatively durable sets of social relations, and both endow their speaker-subjects with power, yet strip them of that power (albeit to varying degrees and within different temporal frameworks, as I shall show) when the speaker-subject moves to and within a different world or institution. I shall explore here the extent to which Melibea is divested of her authority as she moves from the literary institution of courtly love into one in which she is ill-equipped, especially (but by no means solely) linguistically - that is, the carnal and base world of Celestina. I shall focus firstly on the encounters between Melibea and Calisto and the power dynamic of their relationship, and go on to examine the relationship between Melibea and Celestina, which from their first meeting sees the deterioration of any authority that Melibea once held as courtly lady, as language is replaced with carnality and sexual desire, and her status and resources as capital become void. I shall examine the extent to which authority for the two female characters is contingent upon linguistic use and ability within a particular world or institution, and explore the implications for the characters when their linguistic authority depreciates.

In a work that is replete with power struggles, paradoxes, and gender subversions, Rojas subtly juxtaposes his otherwise realistic environment with the unreal, literary presence of courtly love, as expounded by Andreas Capellanus in his twelfth-century treatise De amore (Walsh 1982). F. $X$. Newman sums up the doctrine and its inherent contradictions:

What is striking [about courtly love] is how clearly incompatible it was with conventional medieval views on the psychology and theology of sexuality. It was a habit of the Middle Ages to think man the superior of woman 
[...]. Courtly love involves the contradiction of such [a view] (1968: vii).

An understanding of man as superior is certainly subverted by Rojas from the first scene of the work in which Calisto is portrayed as the desperate and servile lover of amor cortés under the merciless control of his courtly lady, Melibea. With his first words, Calisto elevates Melibea to divine status, «En esto veo, Melibea, la grandeza de Dios» (211), and employs a series of sacred terms to emphasize his devotion to and elevated spiritual yearning for the cruel lady, "el serviçio, sacrificio, devoción y obras pías que por este lugar alcançar tengo yo a Dios ofrescido» (211). ${ }^{1}$ In accordance with the conventions of amor de lonh, even Melibea's absence is sufficient a weapon to wield over the tormented Calisto and achieve authority in the relationship, «me alegro con recelo del esquivo tormento que tu ausencia me ha de causar» (212). ${ }^{2}$ Whilst it has been popular with contemporary psychoanalytical theorists, such as Jacques Lacan (1992) and Slavoj Žižek (1994), to question the apparent domination by the lady in the courtly tradition, such contentions - which envisage scenes of genuine courtly seduction, displacement, and debasement- are inapplicable with regards to a work in which the protagonist is an ineffectual and inept courtly lover (Martin 1972: 110, 111). As such, an attempt to uncover Calisto as the lover in control in the scene - as the knight who empties his lady of all real substance (Lacan 1992: 149) — would be to undermine the skill of Rojas's parodic construction. ${ }^{3}$ In contrast, in terms of the power that she holds over Calisto, Melibea's courtly technique of postponement, of amor interruptus, is successful to the nth degree.

Courtesy and etiquette are crucial features in the economy of courtly love. The abrupt and hyperbolic dismissal with which Melibea closes the first garden scene, «iVete, vete de aý, torpe [...]!» (213), is perhaps a far cry from a contemporary, quotidian understanding of polite behaviour. In the institution of courtly love, however, courtesy and etiquette constitute an exacting protocol, a strict fictional formula or social game. Whether an arrogant young lady who finds herself in a contemptuous situation (Beresford 2001: 50), or a woman whose words here are flirt tious and deliberately provocative (Lacarra 1990: 55), I should suggest that Melibea's words at this stage in the narrative, more importantly, follow by the book the appropriate response suggested by Capellanus for a noblewoman toward a man of the same class, «Nobilis enim muli-

1.- Unless otherwise stated, all references from Celestina are taken from Russell ed. 1991. Numbers in parenthesis refer to page numbers.

2.- For a treatment of the theme of amor de lonh, see Dronke (1965-66: 39-42).

3.- See Martin (1972), whose case for Calisto as a parody of the courtly lover echoes Deyermond's (1961) criticism of Calisto's misuse of the approach set forth in Capellanus's De amore. 
er sive nobilior promptissima reperitur et audax hominis nobilioris facta vel sermones arguere, multumque laetatur si suis ipsum pulchre possit dictis illudere» (Walsh 1982: 158). In employing the literary conventions of courtly love, Melibea is playing - and winning - the social game in which the two characters take part. Her text-book rejoinder, «i[...] que no puede mi paciencia tollerar que aya subido en coraçón humano comigo el ylícito amor comunicar su deleyte!» (213), equates to what Bourdieu, echoing J. L. Austin's "performative utterances» (1962), labels «acts of institution" (1991: 73), which are ways of acting or participating in a ritual and must be uttered by an appropriate person in accordance with some conventional procedure. If efficacy of these utterances or acts are inseparable from the existence of an institution defining the conditions that must be fulfilled in order for them to be effective (Bourdieu 1991: 73), the word, then, is inseparable from both the world in which it is spoken and the world of which it speaks; a world in which Melibea is schooled and words in which she is well-versed, as her reference later in the work to her erudite upbringing shows, "Algunas consolatorias palabras te diría antes de mi agradable fin, coligidas y sacadas de aquellos antigos libros que tú, por más aclarar mi ingenio, me mandavas leer» (589-90). As both Melibea and Calisto are acutely aware, the conventional procedure is amor cortés and the appropriate person is the scornful courtly lady, a role that Melibea assumes with facility given her upbringing, history and literary education, or her habitus.

The Latin term habitus, employed by Aquinas in Summa theologiae to describe the potentialities of a subject with respect to its operational disposition (Holsinger 2005: 100-07), translates in Bourdieu's approach to language and symbolic power to signify a set of inculcated dispositions that allow individuals to act and react in certain ways. Specific practices of perception are the result, Bourdieu stresses, not of the habitus only, but of the relation between the habitus, on the one hand, and the specific social contexts within which individuals act, on the other (1991: 14): the success of the practices in terms of authority depend on a congruence between the two. Bourdieu understands Aquinas's habitus as «a feel for the game» (Holsinger 2005: 100). Melibea's "feel for the game» serves to fulfil the conditions that approve her authority within the specific institution in which the two characters act and re-act - the world of courtly love. In the first scene of Rojas's work, Melibea acts with confidence and speaks with fluency; she incites and beats Calisto "en su propio terreno» (Lacarra 1990: 55), and her adoption of the role of courtly lady together with the protocol that is required of that role ensure her victory. That is not to say, of course, that Calisto does not take pains to shift the balance of power nor that he does not eventually succeed in his attempts. Rojas provides his readers with two points in the narrative that serve to mirror each other in terms of language and (mis)understanding, manipula- 
tion and power. The two parallel meetings between Melibea and Calisto -one in Auto I, the other in Auto XIX - take place in the same garden but in different symbolic worlds, signposting with poignant irony that throughout the course of the narrative the balance of capital has been tipped in Calisto's favour and Melibea's authority is lost.

I shall look first at the figural nature of the garden, in which the two meetings between Melibea and Calisto take place, before going on to consider the shift of symbolic power that occurs between the two garden scenes within the context of that figural interpretation. ${ }^{4}$ June Hall Martin (1972: 81) identifies two types of garden for medieval writers - the Garden of Caritas, whose symbolic values are directed towards portraying the ever-living qualities of God's love, of amor puro, and the Garden of Cupiditas, whose imagery suggests carnal delight and entertainment of the flesh. She notes that the dreamer of the Roman de la Rose sees painted on the outside of the garden walls of Caritas a series of grotesque figures representing the ten qualities of Hate, Felony, Villainy, Covetousness, Avarice, Envy, Sorrow, Old Age, Hypocrisy, and Poverty. The qualities outside will never be able to gain entrance to the Garden of Caritas. In terms of Celestina, Melibea's garden in Auto I is representative of the former of the two antithetical, metaphorical spaces, the Garden of Caritas, and, in penetrating the space, Calisto "makes the mistake of admitting noncourtly qualities into the courtly world» (Martin 1972: 89). ${ }^{5}$ Beyond the physical fracture of the walls, then, Calisto's assault is twofold. In breaking through the lady's garden walls, he metaphorically -and eventually, literally - takes Melibea's virginity. As she later tells her father, the breaching of one barrier equated to the violation of another, «Vencida de su amor, dile entrada en tu casa. Quebrantó con escalas las paredes de tu huerto; quebrantó mi propósito» (588). On a social level, it is within the imaginary society of the garden (Deyermond 1993: 11), a common symbol in courtly love poetry, that Melibea finds her power, her fluenc, and her stability. Calisto's unwanted entry, "jesú! ¡No oyga yo mentar más esse loco, saltaparedes, fantasma de noche, luengo como ciguñal, figura de paramento mal pintado; si no, aquí me caeré muerta!» (316), allows not only the qualities of amor impuro to enter the garden, but threatens to

4.- See Lewis (1977: 119) on the symbolic nature of the garden in the courtly love tradition and Kassier (1976) on the symbol in cancionero poetry.

5.- Louise M. Haywood (2001: 85-88) discusses the admission of negative qualities into the garden enjoyed by Melibea and Calisto within the context of Elicia's curse, which represents a stage in the transformation of the symbolism of the garden from a locus amoenus to a site of destruction: " $\bigcirc$ Calisto y Melibea [...]! ¡Mal fin ayan vuestros amores, en mal sabor se conviertan vuestros dulzes plazeres! [...] Las yervas deleytosas donde tomáys los hurtados solazes se conviertan en culebras, los cantares se os tornen lloro, los sombrosos árboles del huerto se sequen con vuestra vista, sus flores olorosas se tornen de negra color» (525-26). 
diminish Melibea's resources or capital as her world becomes inextricably mingled with the very real and carnal institution of Celestina.

Rojas later makes clear the implications for Melibea when two worlds, ordinarily kept apart, intermingle. During their first meeting, Melibea promises Calisto a reward for his efforts to court her, "Pues aun más ygual galardón te daré yo si perseveras» (212), which Calisto interprets as a sexual proposition, " $\mathrm{O} O$ bienaventuradas orejas mías, que indignamente tan gran palabra havéys oýdo!» (212). Peter E. Russell notes the incongruence between the meaning of the characters' words in relation to the traditional vocabulary of courtly love:

La airada Melibea usa el término, como amenaza, en el sentido corriente de "recompensa» (aquí punitiva); Calisto pretende entenderlo según el léxico del amor cortés en el que "galardón" normalmente se refería a una señal por parte de la dama de que reconocía la devoción a ella del amante. Pero, de acuerdo con el tono paródico del pasaje, el enloquecido mancebo juzga al buen tuntún que Melibea usa la palabra en el sentido de «rendición sexual» (1991: 212).

Calisto may well «juzga al buen tuntún» as Russell suggests (1991: 212) but it is a game at which Melibea - the disdainful and merciless courtly lady - is a far superior opponent. In what has been termed "la furia de Melibea» (Green 1953; Lacarra 1997: 107; Russell 1991), she quickly corrects what the reader before suspected and now knows to be an erroneous interpretation on Calisto's part:

Más desventuradas de que me acabes de oyr, porque la paga será tan fiera qual la merece tu loco atrevimiento, $y$ el intento de tus palabras, Calisto, ha seydo [como] de ingenio de tal hombre como tú haver de salir para se perder en la virtud de tal muger como yó (213; Russell's insertion).

In Auto XIX, during their final encounter in what has become an edenic locus amoenus, there occurs a second miscommunication. Melibea asks Calisto, "¿Señor mío, quieres que mande a Lucrecia traer alguna colación?» (572). Her now lover replies, "No ay otra colación para mí sino tener tu cuerpo y belleza en mi poder» (572). Calisto rejects Melibea's offer of "colación" (572), whether "food for the body or possible nourishment for the mind and soul» (Burke 1993: 353), and transforms the word into a clear sexual euphemism, a metaphor for Melibea's body that will satisfy his animal lust. In his distortion of Melibea's words and the association of food with carnal appetite and sexual favours, Calisto echoes Celestina's words earlier in the narrative that, in recalling the way in 
which she would in her youth devour men with her sharp teeth, relate el coito with la comida:

¿En cortesías y licencias estás? No espero más aquí, yo fiadora que tú amanezcas sin dolor y él sin color. Mas como es un putillo, galillo, barbiponiente, entiendo que en tres noches no se le demude la cresta. Destos me mandavan a mí comer en mi tiempo los médicos de mi tierra quando tenía mejores dientes (379).

Unlike in the first "auto», Melibea leaves Calisto's second (mis)interpretation unchecked. Caritas and cupiditas have fused, and one thing is now certain: in the eighteen "auto" between the two garden encounters, a significant and irreversible change has taken place in terms of the fluency of Melibea's language and the authority that is its corollary. In the first of the two reunions, both Melibea and Calisto play with courtly terms and distort their meaning, but Melibea's role as disdainful lady in the social game of courtly love allows her to have the last word. By the second parallel scene, the situation has been entirely subverted; it is Calisto who manipulates language and dominates the situation. It is not simply the case that Melibea no longer has a "feel for the game» (Holsinger 2005: 100), but that, by the second garden rendezvous in the Garden of Cupiditas, the game itself has irrevocably changed.

Bourdieu suggests that language is always produced in particular contexts or linguistic markets, and the properties of these markets endow linguistic products with a certain legitimate value (1991: 69). In Melibea's institution of courtly love, I have shown that there is a narrow congruence or concordance between her linguistic habitus and the demand of the market, resulting in her authority. By Auto XIX, there is a decided discrepancy between the idealized love that Melibea believes herself to be part of and the crude reality of the affair. The consequences for an understanding of authority in Celestina are extensive. In the first auto, Melibea's authority attests to the fact that the conditions in which she is speaking concur directly with the conditions that endowed her with the authority to speak. By their final encounter, however, there resides an insurmountable incongruence between Melibea's words and the institution into which she has moved: between the courtly words of a once-courtly lady in a non-courtly institution. Melibea's linguistic resources or the capital awarded to her by the institution of courtly love have been assigned a limited value in a market whose demands have changed. John B. Thompson sums up Bourdieu in this respect, concluding that "when there is a lack of congruence [...], an individual may not know how to act and may literally be lost for words» (1991: 17). His words might easily be applied to Celestina and the situation in which Melibea finds herself. In Auto XIX, the lack of congruence between Melibea's words and the world in which 
she utters them is at its greatest. Her way of standing, speaking, walking, and thus of feeling and thinking is critically and permanently distorted, and, as the silence that meets Calisto's distortion of "colación» illustrates, she is lost for the very words that previously awarded her authority.

Such incongruence between habitus and institution, and between capital and the market in which it is assigned value, is brought into sharp focus with the exchange of gifts that highlights the instability of authority in Rojas's shifting worlds. The first gift that makes up the complex web of commercial interactions and economic exchanges of Rojas's plot and the one on which I shall focus here- is Melibea's girdle, which she gives to Calisto, by way of Celestina, «En pago de tu buen sofrimiento, quiero complir tu demanda y darte luego mi cordón» (323). ${ }^{6}$ It is an action that could be seen to empower Melibea in her relation with Calisto, as the lover's adulation of Melibea on receiving the garment reaches new heights. Losing all sense of self-control, as if possessed by the gift, he cries to the girdle, " $\mathrm{O} \mathrm{mi}$ gloria y ceñidero de aquella angélica cintura! Yo te veo y no lo creo. ¡O cordón, cordón!» (350-51). Bourdieu argues that the act of giving is a subtle means of exercising symbolic power, that by giving a gift - especially a generous one that cannot be met by a counter-gift of comparable quality - the giver creates a lasting obligation and binds the recipient in a relation of personal indebtedness within the economy of the system (1990: 126-27). ${ }^{7}$ Whilst his theory coincides with the principle of obligation inherent in medieval gift-giving, it is not aligned with Capellanus's warning to women that a transaction with a man, once executed, cannot be retracted:

Est igitur quam plurimum a mulieribus praecavendum talibus se amatoribus obligare [...]. Ergo quum aliqua postulatur amari, antequam suum largiatur amorem totis suis viribus elaboret postulantis mores et fidem agnoscere, ut nil in eo penitus derelinquat incognitum, quia post peractum incaute negotium, serotinum est sapientis desiderare consilium vel tarda poenitudine castigari (Walsh 1982: 242).

Neither does it account for the disastrous outcome for Melibea, and her complete lack of awareness of what is to come, when those around her can foresee her downfall. Douglas Gifford reminds that «Debemos tener en cuenta que cualquier hombre educado del siglo XI, cualquier hom-

6.- The demonic force behind the gift exchange seems less critical to my argument here than the exchange itself and its subsequent effect on Melibea's authority. See, however, Deyermond 1977 on symbolic equivalence of the gifts and Severin 1995 for more on the subject of witchcraft in the Celestina.

7.- See Harney 1993 and 2005 on kinship and feudal exchange. 
bre que sepa algo de costumbres, usanzas y leyes visigodas, debe estar al corriente de la tradición al don» (1980: 326). If we extend his words to the context of Celestina, Melibea, whose way of thinking, feeling, and behaving is inextricably bound up with customs, usages, and rules, should have been aware of the possible, and indeed probable, ramifications of her gift. She is not conscious, however, of the incongruence that exists, at the moment at which she gives her gift, between her habitus and the world into which she is being drawn -Celestina's.

As Calisto «rapidly comes to identify the girdle with the body which it had encircled, caressing it as well as talking to it in terms appropriate to Melibea herself» (Deyermond 1977: 8), it becomes immediately apparent to the reader, to Melibea's maid Lucrecia, " $i Y a$, ya, perdida es mi ama!» (323), and all-too-late to Melibea herself, «En mi cordón le llevaste enbuelta la posesión de mi libertad» (437) that Melibea, playing increasingly by rules belonging to a world other than her own has allowed an impossible, unconsummated, courtly love to be contaminated with the physical, sexual elements of cupiditas. Calisto, in breaking the walls of Melibea's garden and in his crude and parodic actions, originally allows cupiditas to become intertwined with caritas. Yet, it is Melibea's offering that seals the fate of Celestina's philocaptio. In giving the synecdochic girdle to Calisto, via Celestina, it is Melibea, what is more, who can be understood in terms of a possession. ${ }^{8}$ In allowing herself to become trapped in Celestina's institution of carnality and transaction - a very different institution from the metaphorical, fantasy world of courtly love in which exchange was primarily linguistic and abided by strict rules of courtesy and etiquette-Melibea, "lo no vendible» (572), becomes as exchangeable as the prostitute Areúsa, whose sexuality is «tan comunicable como el dinero» (373). "iNuestro bien todo es perdido!» (595) bemoans Pleberio in his planctus later in the narrative, evoking the concept of bienes - property, money, and other worldly goods. ${ }^{9}$ Playing testament to Rojas's skill of irony, Pleberio sees his daughter — the only thing that matters to him, "Ya sabes que no tengo otro bien sino a ti» (580)_ in need of emotional and financial protection, but Melibea no longer resides in the same world, «Padre mío, no pugnes ni trabajes por venir adonde yo estó» (585). ${ }^{10}$ Neither is the principle loss of capital economic; the loss of Me-

8.- See Gayle Rubin's (1975) article on the traffic in women and the political economy of sex; particularly pp. 169-74 on the relationship between the giving of gifts, kinship, and power.

9.- For an exploration of Pleberio's economic concerns, see Deyermond 1990.

10.- Peter N. Dunn suggests that Pleberio seeks to protect his daughter, but that Melibea is no longer the daughter he speaks of and knows (1976: 411). My argument here is that it is the world in which Melibea acts and reacts that has altered, rather than Melibea herself. It is the incongruity between the two -Melibea's habitus and the world in which she now moves - that makes Pleberio's concerns impossible and ironic. 
libea's linguistic capital and consequent symbolic power was presaged by Lucrecia in Auto Iv (323, cited above) when Melibea surrendered her girdle, long before any loss of economic capital comes to be lamented by Pleberio.

When Melibea meets with Celestina for the first time in the narrative, the old bawd - previously so confident in her position of gain, "Ganemos todos, partamos todos, holguemos todos» (250)— realizes the potential for loss, « $i$ Ce, hermano, que se va todo a perder!» (315). Whilst her aside serves primarily to underline Celestina's genuine belief that the Devil is present during her encounter with Melibea, or to convince the reader of such, it also highlights one of the only points in the narrative when a character foresees his or her own possible loss, and in time to prevent it. Lucrecia envisages her mistress's loss, Pármeno his master's (251, 253), Calisto his own at the point of his death (574), Pleberio witnesses Melibea's loss but after the event. Only Elisa recognizes that «Perdida soy!» (235), and, with Celestina's intervention, manages to salvage the situation. Celestina, on the contrary, is more than aware of the force of her linguistic power over others; when Calisto asks her, «Dime ¿con qué vienes, qué nuevas traes, que te veo alegre y no sé en qué está mi vida?» (445), she replies both manipulatively and knowingly, «En mi lengua» (445). She also recognizes, however, the unstable nature of that power, subject to loss should her incantatory words fail her. Her understanding of the restrictions of her power reflect the liminal position in which she now wields it, before Melibea, whose habitus is one of contemptuous courtly lady, and in a world that used to be but is no longer entirely her own:

$$
\begin{aligned}
& \text { LUC.- Celestina, madre, seas bienvenida. ¿Quál Dios te } \\
& \text { traxo por estos barrios no acostumbrados? } \\
& \text { CEL.- Hija, mi amor: desseo de todos vosotros; traerte } \\
& \text { encomiendas de Elicia, y aun ver a tus señoras, vieja y } \\
& \text { moça. Que después que me mudé al otro barrio no han } \\
& \text { sido de mí visitadas (301). }
\end{aligned}
$$

Celestina used to live and speak in the same world -in spatial terms at the very least - as Pleberio's household, «solía vivir aquí en las tenerías a la cuesta del río» (302). Thus, in Celestina, Rojas also points to the shifting nature of authority as it corresponds to the instability of temporal worlds, as well as spatial institutions. Celestina recognizes that her authority was at its greatest "en mi tiempo» (379), when she was younger, at her physical and sexual peak, and when punishments meted out to prostitutes were less severe. ${ }^{11}$ As María Rosa Lida de Malkiel (1962: 514) and Dorothy Sherman Severin (1995: 47) note, the power that Celestina 
has in the temporal limits of Rojas's work does not compare favourably to the authority that she exercised in her past.

Celestina straddles Rojas's worlds; a go-between through which caritas and cupiditas intermingle. Elena Gascón Vera's (1983) comparison of Boethius's Philosophia and Celestina helps to illustrate the inter-institutional position of the old bawd. Gascón Vera draws parallels between "diálogo boeciano», which she considers to be «de carácter vertical» between a superior and inferior character, and Petrarchan dialogue, a horizontal dialogue «entre iguales» (1983: 4). Celestina moves between these dialogues throughout Rojas's work: she professes, for example, to speak to Sempronio as equal, «Pero di, no te detengas; que la amistad entre ti y mí se afirma no ha menester preámbulos ni correlarios ni aparejos para ganar voluntad» (237-38), but at the same time mixes camaraderie with the enmity of one who is superior, «Escucha y déxame hablar lo que a ti y a mí conviene» (248). Upon death, as throughout the work, Celestina, the "masterful interactant» (Read 1978: 171), vacillates between the two dialogues - between Boethian dialogue, which she uses in admonition, in an attempt to reassert her failing authority, "¿Quién só yo, Sempronio? ¿Quitásteme de la putería? Calla tu lengua, no amengües mis canas, que soy vieja qual Dios me hizo, no peor que todas» (482), and Petrarchan dialogue, that ostensibly seeks to position Sempronio and Pármeno as her intellectual equals in verbal mastery, "como dizen: «el duro adversario entibia las yras y sañas» (484). Threatened in her own house, however, Celestina's linguistic liminality leads inexorably to her demise; at her death, Celestina, for the first time, fails to use that liminality to her advantage, and loses all control of the situation, of her interactants, and, ultimately, of herself. Celestina is undisputed master within the walls of her own house - representative of the institution of carnality and exchange that has brought about Melibea's demise. Sempronio, however, in coming to look for Celestina in her own house, in her own neighbourhood, and enlist her services, penetrates the institution in which she has utmost authority, just as Calisto did Melibea's. As the grip of her power begins to loosen, Celestina tells Sempronio and Pármeno, «Vivo de mi oficio como cada qual oficial del suyo, muy limpiamente. A quien no me quiere, no le busco. De mi casa me vienen a sacar. En mi casa me ruegan. [...] Déxame en mi casa con mi fortuna» (482-83). Her fortune, her capital, however, is no longer her own, as she has promised - albeit falsely - to share it with others:

SEM.- ¿No serás contenta con la tercia parte de lo ganado?

CEL.- ¿Qué tercia parte? Vete con Dios de mi casa tú. Y essotro no dé vozes, no allegue la vezindad (484). 
When Sempronio and Pármeno arrive at Celestina's door for the last time, Sempronio tells the bawd, "Que si estimarse pudiesse a lo que de allí nos queda obligado, no sería su hazienda bastante a complir la debda, si verdad es lo que dizen, que la vida y persona es más digna y de más valor que otra cosa ninguna» (476). In terms of economy and exchange, by the end of the narrative, the shortfall between Celestina's debts and the capital available to her is insurmountable. Within the context of symbolic power and linguistic capital, Celestina, who shifts between institutions, finds herself lost for words. The old bawd attempts to her last breath to maintain a Boethian dialogue, spoken between a superior and an inferior speaker-subject, in which she retains her fortune, but is forced by Sempronio and Pármeno to interact in a dialogue between equals, in which capital and gains are shared. As a result, at the point of her death, she resides in a liminal position between the two dialogues that constitute her language, with neither linguistic nor economic capital at her disposal.

Celestina's and Melibea's authority is at its apogee in contrasting institutions. Yet, the two characters share the inability to return to the institution in which they were first recognised as having authority. Celestina's old age and lack of sexual prowess prevent her from exercizing the power that she once did in her prime - she is temporally removed from the world that awarded her maximum symbolic power. Melibea is utterly incapable of returning to the habitus of her old institution, as her suicide demonstrates. She can regain neither her lost virginity, "Perdí mi virginidad» (588), nor her lost memory in which her habitus is inscribed, "ya la dañada memoria, con la grand turbación, me las ha perdido» (590). ${ }^{12}$ In the same way that the language of courtly love is debased by its use in Celestina's underworld, Melibea's sens pratique, that is her state of body, of being (Bourdieu 1991: 13), has been corrupted by her move into an institution (Celestina's) in which she is alien. In the penultimate auto, the language that Melibea uses and the reason that she desperately seeks are no longer available to her; they reside in the Garden of Caritas, within the walls of the institution that she left behind. If, for Melibea at the point of her death, "the breakdown of dialogue here signifies the breakdown of authority» (Shipley 1968: 104), the collapse first of Celestina's Petrarchan dialogue and secondly of her Boethian dialogue signifies the demise of her authority over Pármeno and Semprono first as equals and then as their superior. Celestina's linguistic skill wanes irrevocably, whilst Melibea's authority is reduced to the ability only to take her own life. Her relationship with Calisto takes place in the literary world of courtly tradition, and the power inherent in Melibea's word operates within that world, as the institution awards her the authority to speak, and, moreo- 
ver, to speak with authority. The courtly world, both spoken of and spoken in, becomes distorted and replaced with a very different, real world -real in the sense that words become realized, literary concepts become literalized-, a world in which Melibea is no longer recognized as an authorized speaker-subject. After losing the authority to speak, Melibea's loss of power, and death, follow closely behind. Authority is contingent on the world spoken of, a fact illustrated both by the loss of Melibea's authority as Celestina's values penetrate her world of amor cortés, and as Celestina, at the same time, allows others to share in her profit - symbolic and economic - and perishes as a result.

Basing his contention on Stephen Gilman's «técnica de concretización» (1974: 383), Kassier draws a comparison between the transition in Rojas's work from literary to real — «The metaphors are removed from their lyrical, figurative context, a context in which they are still images, and are made real by being placed in the "real» context of Celestina» (1976: 19) —, and the external, actual, transition of the epoch, «In its broadest sense the work juxtaposes the senescent Middle Ages with the nascent Renaissance by contrasting the conventions of an essentially medieval poetry with the realities of a new societal arrangement» (1976: 27-28). Melibea's move from the courtly institution in which gifts constitute feudal exchange and love is transcendental and eternal, corresponds to the transition from a whole mode of existence that was drawing to a close in the Middle Ages towards the increasingly vigorous spirit of the Renaissance. Rojas intentionally juxtaposes the new, urban, and commercial society of the Renaissance with the increasingly irrelevant feudal society of the waning Middle Ages, embodied in what Erna Ruth Berndt calls «toda aquella estilización del amor cortés, que iba careciendo más y más de sentido hacia fines de la Edad Media» (1963: 23). In doing so, the author's pessimism, partly indicative of the general philosophical crisis of the late fifteenth century (Severin 1987: xii), subtly attacks authority in his fictional world of courtly love. Rojas also, however, destabilizes the notion of a firm and lasting authority in Celestina's world-the urban society of Renaissance Spain. Celestina thrives —or thrived- in the urban, commercial society of her youth, and embodies perversely the vigorous spirit of the Renaissance. ${ }^{13}$ Yet her authority also falters in Rojas's work with fatal consequences. She alternates between institutions and between dialogues, and finds herself eventually in linguistic no-man's land. She attempts immediately before her death to return to the institution in which she was originally authoritative, but finds herself - like Melibea - powerless within the walls of her own domain. Celestina's

13.- Gascón Vera considers Celestina's attitudes towards life, her search for extrospective and immediate pleasure, to pertain to a Renaissance, rather than a medieval consciousness (1983: 9). 
authority has not changed; in Rojas's work it is the linguistic economy of the institution, not the character, that awards and determines authority, but that institution, once distorted, cannot be bent back into shape and the character's linguistic capital that becomes lost as a result cannot be replenished. Melibea and Celestina both possess authority within and according to the rules and laws of their own separate worlds, and lose it when their worlds are breached and begin to resemble each other's. In this way, Rojas undermines mercilessly the notion of stable authority in both the old world of medieval values and the new society of renaissance conduct, and in both the literary context of courtly love and the institution of carnality and exchange in which performative utterances are literalized. The rules of Rojas's worlds and the protocol of Bourdieu's fields or institutions parallel one another: players in a field must have a sense of what is at stake, an investment in the outcome, a mastery of strategies required for success, and above all, a talent for innovation within continuously changing circumstances (Verter 2003: 152). Celestina's strategic game plan and understanding of what is at stake, and Melibea's investment in the outcome of her carnal relationship with Calisto are incontestable. Neither Melibea nor Celestina, however, holds sufficient talent for innovation in order to remain empowered, or indeed even survive, within the shifting and destabilizing worlds of Rojas's work.

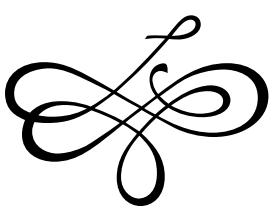




\section{Works Cited}

\section{Primary Works}

Austin, J. L., How To Do Things With Words, The William James Lectures, Oxford, Clarendon Press, 1962.

Bourdieu, Pierre, The Logic of Practice, trans. Richard Nice [Le sens pratique, Paris, Minuit, 1980], Cambridge, Polity Press, 1990.

_, Language and Symbolic Power, ed. John B. Thompson, trans. Gino Raymond \& Matthew Adamson, Cambridge, Polity Press, 1991.

Capellanus, Andreas, De amore, ed. \& trans. P. G. Walsh, Duckworth Classical, Medieval and Renaissance Editions, London, Duckworth, 1982.

Lacan, Jacques, The Ethics of Psychoanalysis, ed. Jacques-Allain Miller, trans. Dennis Porter [Le Seminaire, 7: L'ethique de la psychanalyse 1959-1960, Paris, Seuil, 1986], London, Routledge, 1992.

Rojas, Fernando de, Celestina, ed. Dorothy Sherman Severin, Warminster, Aris \& Phillip, 1987.

Rojas, Fernando de, Comedia o tragicomedia de Calisto y Melibea, ed. Peter E. Russell, Clásicos Castalia 191, Madrid, Castalia, 1991.

Žlžer, Slavoj, The Metastases of Enjoyment: Six Essays on Woman and Causality, London, Verso, 1994.

\section{Secondary Works}

Beresford, Andrew M., "Una oración, señora, que le dixeron que sabías, de Sancta Polonia para el dolor de las muelas': Celestina and the Legend of St Apollonia», Bulletin of Hispanic Studies, 78 (2001), pp. 39-57.

Berndt, Erna Ruth, Amor, muerte y fortuna en 'La Celestina', Madrid, Gredos, 1963.

Burke, James F., "Law of the Father - Law of the Mother", in Fernando de Rojas and 'Celestina': Approaching the Fifth Centenary: Proceedings of an International Conference in Commemoration of the $450^{\text {th }}$ Anniversary of the Death of Fernando de Rojas, Purdue University, West Lafayette, Indiana, 21-24 November, 1991, eds. Ivy A. Corfis \& Joseph T. Snow, Madison, HSMS, 1993, pp. 350-54.

Deyermond, Alan, "The Text-Book Mishandled: Andreas Capellanus, and the Opening Scene of La Celestina», Neophilologus, 45 (1961), pp. $218-21$.

—, "Hilado-Cordón-Cadena: Symbolic Equivalence in La Celestina», Celestinesca, 1.1 (1977), pp. 6-12. 
-, «Pleberio's Lost Investment: The Worldly Perspectives of Celestina, Act 21», Modern Language Notes, 105 (1990), pp. 169-79.

-, "Female Societies in La Celestina", in Fernando de Rojas and 'Celestina': Approaching the Fifth Centenary: Proceedings of an International Conference in Commemoration of the $450^{\text {th }}$ Anniversary of the Death of Fernando de Rojas, Purdue University, West Lafayette, Indiana, 21-24 November, 1991, eds. Ivy A. Corfis \& Joseph . Snow, Madison, HSMS, 1993, pp. 1-31.

Dronke, Peter, Medieval Latin and the Rise of European Love Lyric: Problems and Interpretations, Oxford, Clarendon Press, 1965.

Dunn, Peter N., «Pleberio's World», PMLA, 91 (1976), pp. 406-19.

Gascón Vera, Elena, "Celestina, Dama Filosofía», Celestinesca, 7.2 (1983), pp. 3-10.

GIFFORD, Douglas, "Un ratón en la cerveza", Actas del congreso internacional de hispanistas celebrado en Toronto del 22 al 26 agosto de 1977, Toronto, Asociación internacional de hispanistas \& University of Toronto, 1980, pp. 325-28.

Gilman, Stephen, 'La Celestina': arte y estructura, Persiles, 71, Madrid, Taurus, 1974.

Green, Otis H., «La furia de Melibea», Clavileño, 4 (1953), pp. 1-3.

Harney, Michael, Kinship and Polity in the Poema de Mio Cid, Indiana, Purdue University Press, 1993.

-, "Amity and Polity in Spanish Chivalric Romances», in Historicist Essays on Hispano-Medieval Narrative: In Memory of Roger M. Walker, eds. Barry Taylor \& Geoffrey West, Publication of the Modern Humanities Research Association, 16, London, Maney Publishing for the Modern Humanities Research Association, 2005, pp. 135-70.

HaYwOoD, Louise M., "Models for mourning and magic words in Celestina", in Context, Meaning and Reception of 'Celestina': A Fifth Centenary Symposium, eds. Ian Michael \& David Pattison, BHS Special Issue, Abingdon, Glasgow University, 2000, pp. 81-88.

Holsinger, Bruce, The Premodern Condition: Medievalism and the Making of Theory, Chicago, University Press, 2005.

Kassier, Theodore L., "Cancionero Poetry and the Celestina: From Metaphor to Reality", Hispanófila, 56 (1976), pp. 1-28.

LaCARra, María Eugenia, Cómo leer 'La Celestina', Cómo Leer, 5, Madrid, Júcar, 1990.

—, «La ira de Melibea a la luz de la filosofía moral y del discurso médico", in Cinco siglos de Celestina: aportaciones interpretativas, eds. Rafael Beltrán \& José Luis Canet, València, Universitat de València, 1997, pp. 107-20.

Lewis, C. S., The Allegory of Love: A Study in Medieval Tradition, London, Oxford University Press, 1977.

Lida de Malkiel, María Rosa, La originalidad artística de 'La Celestina', Argentina, Universitaria de Buenos Aires, 1962. 
Martin, June Hall, Love's Fools: Aucassin, Troilus, Calisto and the Parody of the Courtly Lover, Colleción Támesis, A.21, London, Támesis, 1972.

Newman, F. X., The Meaning of Courtly Love, Albany, State University of New York Press, 1968.

ReaD, M. K., "Fernando de Rojas' Vision of the Birth and Death of Language», Modern Language Notes, 93 (1978), pp. 163-75.

Rubin, Gayle, "The Traffic in Women: Notes on the 'Political Economy' of Sex", in Toward an Anthropology of Women, ed. Rayna R. Reiter, New York, Monthly Review Press, 1975, pp. 157-210.

Severin, Dorothy Sherman, Memory in 'La Celestina', Colleción Támesis, A.19, London, Támesis, 1970.

-, Witchcraft in Celestina, Papers of the Medieval Hispanic Research Seminar, 1, London, Dept. of Hispanic Studies, Queen Mary \& Westfield College, 1995.

ShIPLeY, George A., "Authority and Experience in La Celestina», Bulletin of Hispanic Studies, 62 (1968), pp. 95-111.

VERTER, Bradford, «Spiritual Capital: Theorizing Religion with Bourdieu against Bourdieu", Sociological Theory, 21 (2003), pp. 150-74.

WEST, Geoffrey, «The Unseemliness of Calisto's Toothache», Celestinesca, 3 (1979), pp. 3-10.

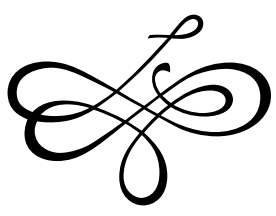




\section{Gatland, Emma, «Language and Authority in the Celestina: Institutions, Incongruence and Shifting Symbolic Power", Celestinesca 31 (2007), pp.85-102.}

\section{RESUMEN}

George Shipley (1968) sostiene que el poderío de las palabras funciona transitivamente en el mundo del que se habla. Tres silogismos que estudiaré en este artículo son inherentes a este argumento: existen mundos alternativos en la Celestina aparte del mundo del que se habla. En la obra de Rojas, el lenguaje funciona dentro de y según estos mundos ficticios; el lenguaje tiene valores contradictorios y por eso la autoridad lingüística puede depreciarse o revalorizarse. Empleando la teoría del sociólogo francés Pierre Bourdieu, que reconoce la legitimidad del poderío lingüístico según las construcciones sociales en que funciona, investigo los cambios del ejercicio del poder en el discurso de Melibea y Celestina, con el fin de probar que cuando se entremezclan los mundos ficticios (el amor cortés y la prostitución) la autoridad lingüística se ve afectada irrevocablemente y que el lenguaje en la Celestina desestabiliza en la misma proporción en la que otorga poder.

PALABRAS CLAVE: lenguaje, autoridad, instituciones, poder simbólico, Bourdieu.

\section{ABSTRACT}

George Shipley (1968) writes that the power inherent in the word operates transitively in the world spoken of. Bound up in this statement are three syllogisms that I shall examine in this article: that there exist different worlds in the Celestina other than the one spoken of; that language operates in Rojas's work within and according to these fictional worlds; and that language has contradictory values and linguistic power can thereby be continually transmuted. Making use of theory propounded by Pierre Bourdieu, which acknowledges the legitimacy of linguistic authority according to the social constructions in which it is embedded, I shall explore the shift in verbal mastery of Melibea and Celestina, arguing that the intermingling of fictional worlds - of courtly love and prostitution - affects irrevocably their linguistic authority and that language in the Celestina destabilizes as much as it can empower.

KEY WORDS: Language, Authority, Institutions, Symbolic Power, Bourdieu. 